\title{
Bloom Syndrome Protein
}

National Cancer Institute

\section{Source}

National Cancer Institute. Bloom Syndrome Protein. NCI Thesaurus. Code C17980.

Bloom syndrome protein (1417 aa, 159 kDa) is encoded by the human BLM gene. This protein plays a role in DNA replication and cell division. 